\title{
ANALYZING THE CONTRIBUTION OF CRITICAL THINKING SKILLS AND SOCIAL SKILLS ON STUDENTS' CHARACTER BY APPLYING DISCOVERY LEARNING MODELS
}

\section{Hariyanto ${ }^{1}$ \\ Mohamad Amin ${ }^{++}$ \\ Susriyati Mahanal ${ }^{3}$ \\ Fatchur Rohman ${ }^{4}$}

\author{
Universitas Negeri Malang, Faculty of Mathematics and Natural Sciences, \\ Indonesia; Universitas PGRI Argopuro Jember, Faculty of Mathematics and \\ Natural Sciences, Indonesia. \\ 'Email: ghost.ary1@gmail.com \\ ${ }_{2,, 4}^{2,4}$ Universitas Negeri Malang, Faculty of Mathematics and Natural \\ Sciences, Indonesia. \\ ${ }^{2}$ Email:mohamad.amin.fmipa@um.ac.id \\ ${ }^{s}$ Email: susriyatimahanal.fmipa@um.ac.id \\ Email:fatchur.rohman.fmipa@um.ac.id
}

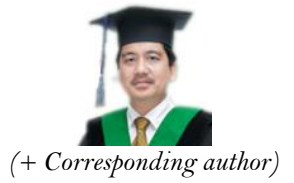

(+ Corresponding author)

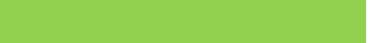

Article History

Received: 6 August 2020 Revised: 20 December 2021 Accepted: 4 January 2022 Published: 19 January 2022

Keywords

Character

Critical thinking skills

Discovery model

Social skills

Students' character.

\begin{abstract}
Character education gets a lot of attention from stakeholders and educators to be developed; hence, many models have been created to develop the affective domain. This study aimed to analyze the relationship and contribution of critical thinking skills and social skills with students' character through the application of discovery models. The population of this study were high school students in Situbondo. The research sample was chosen from SMA Negeri 1 Besuki with the purposive sampling method. The research instrument to measure critical thinking skills was an essay test developed from Facione's critical thinking skills rubric. Social skills were measured using instruments adopted from Social Skills inventory. To examine students' character, observation sheets were developed from six pillars of character element of the Josephson Institute. The validity and reliability of the instruments were performed before using them. The results of the validity calculation with product-moment correlation analysis and the reliability calculation with Cronbach's alpha analysis showed that the instrument was valid and reliable so that it could be used in this study. Data were analyzed using multiple regression. The results showed critical thinking skills and social thinking skills together had a contribution to the development of students' character in the application of discovery learning models. This research can be a reference for readers about the contribution of students' critical thinking skills and social skills to developing students' character. Further research is needed to find out other impacts that affect students' character.
\end{abstract}

Contribution/Originality: This study contributed to finding how a person's critical thinking skills and social skills contributed to the development of good character in his life, especially when character development focused on developing external factors through learning in schools.

\section{INTRODUCTION}

The importance of character education began to emerge in Indonesia since mid-2010 when the implementation of "serasehan" was carried out by the national education ministry. Even though long before that, the functions and objectives of national education had mandated the government to develop character education for students as stipulated in the (UUSPN, 2003). America began to realize the importance of character education in early 1990 s and Korea in 1995 (Lee, 2001). The importance of character education started from the view that was developed in 
several countries which stated that the decline of students' character can result in a deterioration in the power of thought and social relations between people (Peterson, Park, Pole, D’Andrea, \& Seligman, 2016). Character refers to the tendency to act in ways that are consistent with what people understand to be morally right (Lee, 2001). Character is also interpreted as a basis for ways of acting, thinking, behaving and viewpoints based on the results of internalization of various policies (Puskur, 2010). The virtue of character can be related to cognitive approaches in terms of subject's efforts to understand and restructure certain situations (Logan, Kilmer, \& Marlatt, 2010). Integration of character education through every lesson in school is mostly done because it is believed to make students have strong positive characters and take root in their lives (McGovern \& Miller, 2008). Teachers are required to inculcate character education not only through moral and religious education, but in all subjects through models that can adopt students' character development measures (Lee, 2001).

The current education system does not pay attention to character development (Lee, 2001). This can be seen from the fact that students today are smarter than students in the past but engaging in more unethical behavior. This is further evidence to support the claim that current character education in schools has not been very effective in helping students develop healthy moral character (Lee, 2001; Peterson et al., 2016). The effects of character education to increase student success in school have been felt in America since the 1990s (Lee, 2001). The concept of character education has also been applied in Korea since 1995, which emphasizes changes in education to enhance the development of good moral character and creativity in students (Gustems-Carnicer \& Calderón, 2016; Lee, 2001). Malaysia began implementing moral education in 1993 on the moral provision that non-Muslim students should attend moral education classes that were given at the same time when Muslim students studied Islamic Religious Education, and both were included in the list of subjects tested (Sultoni, 2016; Sumintono, Tahir, Anuar, \& Rahman, 2012). Character education in Indonesia has been carried out since the pre-independence era, both through schools and pesantren. Character education at that time was known as Pancasila moral education or religious education, but since May 2, 2010, the Minister of National Education began officially launched the application of character education through "serasehan" events (Sultoni, 2016; Sumintono et al., 2012). Several studies have found a link between how a person's character influences thinking patterns and how to interact with others (Logan et al., 2010; Peterson et al., 2016). Someone who has higher critical thinking skills can understand the problem more deeply and try to restructure certain situations preceded by a positive character that is internalized in his soul (Logan et al., 2010).

Critical thinking is a careful evaluation of an active thought process, aware of the evidence and its consequences, and open to change and self-improvement (Fisher, 2001; Lipman, 2003). Critical thinking is also defined as a logical reflective thinking that is focused on helping in making judgments or making decisions when faced with problems (Paul \& Elder, 2012; Ritchhart \& Perkins, 2005). Critical thinking can analyze, apply, conceptualize, synthesize, and evaluate information produced by observation, reasoning, experience, communication, or reflection, as guidelines for beliefs and actions (Allen, 2008; Beyer, 1987; Canziani \& Tullar, 2017). Individuals with high critical thinking skills also tend to be able to manage their behavior to do good and avoid disgraceful behavior (Scriven \& Paul, 1987). They can control and process emotions so that the actions they cause will be very careful, have a strong character and good self-management (Eggen \& Kauchak, 2012). They are also able to filter the information received and take measured actions to respond to Paul, Binker, Martin, Vetrano, and Kreklau (1989). Besides having a link between a person's character and his critical thinking, one's character also has a close relationship with one's social skills (Unlu, 2018). Individuals with a strong character will have a human spirit, simplicity and high social attitude (Logan et al., 2010). They can establish meaningful communication and can avoid disgraceful behavior (Lee, 2001; Logan et al., 2010). Individuals with good character show good interaction patterns, establish positive cooperation both in the classroom environment and outside the classroom environment and have many connections needed for school success (Weber \& Ruch, 2012). Social skills are defined as social behaviors that govern the effectiveness of daily interactions (Canney \& Byrne, 2006). Social skills are also 
defined as the skills needed to interact well with others (Wong et al., 2015). Brooks, Floyd, Robins, and Chan (2015) define social skills as a set of knowledge used to observe a person's behavior and use it to interact with others so that positive feedback can be obtained. Social skills are needed to overcome difficulties in interpersonal relationships which if left unchecked will be at risk of negative things, such as dropping out of school, juvenile delinquency, adult psychopathology, depression, and suicide (Gresham, 2016; Gresham, Elliott, Cook, Vance, \& Kettler, 2010). Good social skills will make someone have a good social character, not monopolize the conversation or cut off the conversation of others (Hopkins et al., 2011).

Social skills are also the motor of student success in the classroom, interaction with students and teachers, collaboration skills and rapid response to changing environmental conditions are key to making them academically successful (Hughes et al., 2011; Kroeger, Schultz, \& Newsom, 2007; Laushey \& Heflin, 2000). Social skills control a person how to act, say and think when interacting with others (Lerner, McMahon, \& Britton, 2013; McMahon, Vismara, \& Solomon, 2013). Research on the influence of discovery learning strategies on critical thinking skills, social skills and character has been widely carried out. Mawaddah, Suyitno, and Kartono (2015); Syolendra and Laksono (2019) suggest that discovery learning can improve students' integrated and creative thinking skills.

Asrul and Susilo (2018) report that thinking skills, creativity, motivation and mastery of concepts can be significantly improved through discovery learning models. Discovery learning models can improve student learning outcomes (Suphi \& Yaratan, 2016; Uside, Barchock, \& Abura, 2013). Other findings reveal that the discovery model can improve students' critical thinking skills (Martaida, Bukit, \& Ginting, 2017; Purwanto, Nugroho, \& Wiyanto, 2012). Besides that, Discovery models are also able to improve learning outcomes and metacognitive skills (Abdelrahman \& Abdelrahman, 2014; Akinbobola \& Afolabi, 2009).

Discovery models can improve student problem solving (Efendy, 2011) and build students' character (Feriyanti, 2014). It is evident that none of these studies have discussed the relationship and contribution of critical thinking skills and social skills with students' character using discovery models. Therefore, it is important to uncover the relationship between critical thinking skills and social thinking skills on students' character in the application of discovery models and find out the extent to which the impact of this relationship. The findings of this research can be used as a basis for information and recommendations for the application of discovery models to improve the quality of learning.

\section{METHOD}

\subsection{Research Design}

This study adopted correlational descriptive research design using control and experimental groups, with one group took the dual pretest-posttest design, whereas another group took only the pre-test value followed by treatment and post-test value as presented in Table 1.

Table 1. One group design pretest-posttest.

\begin{tabular}{l|c|c}
\hline Pretest & Treatment & Posttest \\
\hline $\mathrm{O}_{1}$ & $\mathrm{X}$ & $\mathrm{O}_{2}$ \\
\hline Note: O1: Pretest value. \\
X: Treatment with discovery models. \\
O2: posttest value.
\end{tabular}

This study recorded two observations, one, which was carried out before the treatment called pretest (O1) and second observation, made after the treatment called posttest $(\mathrm{O} 2)$. This research can be called a correlational study since it aimed to uncover the relationship of critical thinking skills and social skills with students' character through the application of discovery learning models. 


\subsection{Research Sample}

This research took place at SMA Negeri 1 Besuki in the academic year 2018-2019. SMA Negeri 1 Besuki was chosen due to the strategic location of the school that reflected the culture and character of the Situbondo community, which made it a representative sample for this study. Another reason for selecting this research setting was the openness of the school to accept educational innovation. The sample of this study comprised 34 students of class XI Science 3, with 14 male students and 20 female students, selected from the Excretory System Biology subjects

\subsection{Research Instruments and Procedures}

The data of this study mainly comprised the test results of critical thinking skills essay test, the results of observations of social skills on a rubric and observation sheets of students' character. The instrument for measuring critical thinking skills was an essay test which contained 15 items. The critical thinking skills rubric adopted the Facione (1990) critical thinking rubric developed by Zane (2013) on a scale of 1-4. The social skills rubric was adopted from SSI (Social Skills inventory) developed by Novotni (2002) consisting of basic abilities, verbal communication skills, non-verbal communication skills, self-care, self-control, the ability to establish relationships, and the ability to block communication. The responsibility character observation sheet was developed from the six pillars of character from the Josephson Institute. bservations of students' social skills and their character were carried out throughout the learning process. The researcher was assisted by two observers who noted students' character and their social skills during the experiment on observation sheets. As a part of research instrumentation, all participants were provided excretion system material with discovery models during all the four meetings. In the end of learning, the researcher asked a few questions to assess students' critical thinking skills based on material that had been given previously.

\subsection{Validity and Reliability}

The validity and reliability of the items were obtained through trials conducted in class XII students who had received the material in advance. The selection of class XII was made to ensure that there was no bias towards the results obtained and the questions that were to be tested should not be retained by class XI students when they actually took the test. The results of the calculation of validity with product-moment correlation analysis showed that each item had a correlation value greater than 0.0749. It can therefore be concluded that all the items tested in this study were valid. The reliability test results with Cronbach's alpha analysis on the problem of critical thinking skills as a whole also showed a value of 0.254 , which is greater than the minimum value of 0.06 set by Cronbach's Alpha. Based on the results of these calculations it was concluded that overall all items of critical thinking skills had a strong reliable value.

\subsection{Data Analysis}

The data was analyzed using multiple regression analysis to reveal the relationship between critical thinking skills and social skills of students' character. Normality test and homogeneity test were carried out before testing the hypothesis with the help of SPSS 26 at a significance level of $5 \%$.

\section{RESULTS}

\subsection{Assessment Validity and Reliability}

Before conducting the hypothesis test, the parametric test assumptions were carried out namely the normality test and the data homogeneity test. The normality test results of critical thinking skills, social skills and character of students were $0.067,0.072$ and 0.102 , so it can be concluded that the data was normally distributed. 
Homogeneity test results of students' character based on critical thinking skills and social skills respectively were 0.913 and 0.554 results which concludes that data variance was homogeneous.

\subsection{Assessment Data on Correlation Variable}

The results of the correlation analysis between critical thinking skills and social skills on students' character in the application of discovery models are presented in Table 2 which shows that the results of ANOVA analysis are statistically very significant (0.000), and illustrates that critical thinking skills and social skills have a strong correlation with students' character on the application of discovery learning models.

Table 2. Summary of ANOVA on the correlation between critical thinking skills and social skills on students' character

\begin{tabular}{c|c|c|c|c|c|c}
\hline \multicolumn{2}{c|}{ Model } & Sum of Squares & df & Mean Square & F & Sig. \\
\hline \multirow{3}{*}{1} & Regression & 1214.111 & 2 & 607.055 & 54.751 & $0.000^{\mathrm{b}}$ \\
\cline { 2 - 7 } & Residual & 365.889 & 33 & 11.088 & & \\
\cline { 2 - 7 } & Total & 1580.000 & 35 & & & \\
\hline
\end{tabular}

b. Predictors: (Constant), social, critical thinking.

\subsection{Assessment Data on Multiple Regression}

The results of the multiple regression analysis between critical thinking skills and social skills on students' character in the application of discovery learning models are presented in Table 3. Based on Table 3, the magnitude of the relationship between critical thinking skills and social skills simultaneously on students' character was calculated. The correlation coefficient $(\mathrm{R})$ of 0.886 shows a strong relationship between critical thinking skills and social skills on character, while the simultaneous contribution of critical thinking skills and social skills on students' character (R2) is $78.5 \%$ while the remaining $21.5 \%$ is determined by other variables. Table 3 provides information on the probability value (Sig. F Change) of 0.000 , this value can be interpreted that critical thinking skills and social skills are simultaneously and significantly related to students' character.

Table 3. Summary of correlation regression between critical thinking skills and social skills on students' character.

\begin{tabular}{|c|c|c|c|c|c|c|c|c|c|}
\hline \multirow[b]{2}{*}{ Model } & \multirow[b]{2}{*}{$\mathbf{R}$} & \multirow[b]{2}{*}{ R Square } & \multirow[b]{2}{*}{$\begin{array}{l}\text { Adjusted R } \\
\text { Square }\end{array}$} & \multirow{2}{*}{$\begin{array}{c}\text { Std. Error } \\
\text { of the } \\
\text { Estimate }\end{array}$} & \multicolumn{5}{|c|}{ Change Statistics } \\
\hline & & & & & $\begin{array}{c}\text { R Square } \\
\text { Change }\end{array}$ & $\begin{array}{c}\mathbf{F} \\
\text { Change }\end{array}$ & df 1 & dfe & Sig. F Change \\
\hline 1 & $0.877^{\mathrm{a}}$ & 0.768 & 0.754 & 3.330 & 0.768 & 54.751 & 2 & 33 & 0.000 \\
\hline
\end{tabular}

\subsection{Assessment Data on Correlation Regression Coefficients}

The results of the correlation regression coefficients presented in Table 4 provide more information about the variables that have a strong correlation to students' character. Table 4 presents the value of Sig. Critical thinking skills as 0.005 , a value which is smaller than 0.05, This means that critical thinking skills have a significant effect on students' character, while the value of sig. social skills are 0.545 , a value greater than 0.05 , which means that social skills do not have a significant effect on students' character

Table 4. Regression coefficient correlation between critical thinking skills and social skills on students' character.

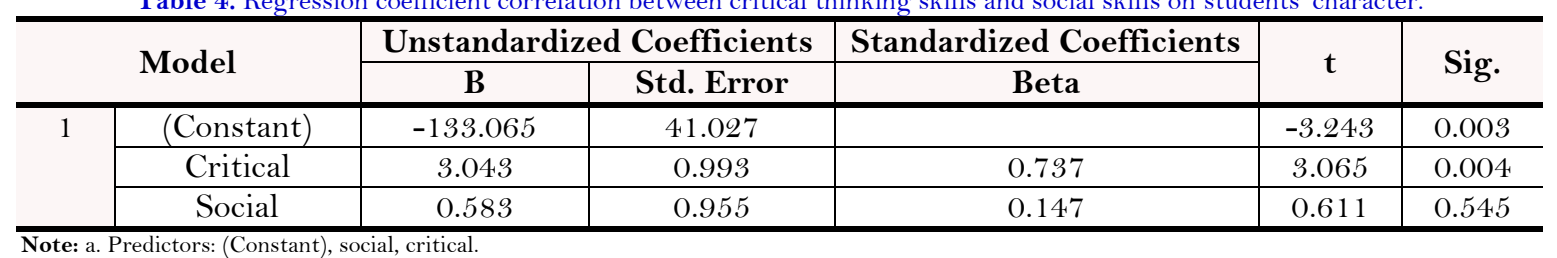




\subsection{Assessment Data on Effective Contributions of the Predictors}

The number of relative and effective contributions of independent variables (predictors) to dependent variable (criteria), namely students' characters, is presented in Table 5 which shows that the relative contribution of critical thinking skills to students' characters is $83.96 \%$, and the relative contribution of social skills is $16.04 \%$. The effective contribution of critical thinking skills to students' characters is $64.49 \%$, and the effective contribution of social skills to students' characters is $12.32 \%$. Thus, the total effective contribution is $76.81 \%$. Therefore, it can be concluded that critical thinking skills have a greater contribution to students' character than social skills.

Table 5. Contribution of critical thinking skills and social skills to students' character.

\begin{tabular}{l|c|c}
\hline Variable & Relative Contribution (\%) & Effective Contribution (\%) \\
\hline X1 (Critical Thinking) & 83.96 & 64.49 \\
\hline $\mathrm{X} 2$ (Social skills) & 16.04 & 12.32 \\
\hline Total & 100 & 76.81 \\
\hline \multicolumn{2}{l}{ Note: a. Predictors: (Constant), social, critical. }
\end{tabular}

\section{DISCUSSION}

The results of multiple linear regression analysis revealed that critical thinking skills and social skills can effectively improve students' character. These results indicate that there is a very strong correlation between critical thinking skills and social skills in relation to students' character. The contribution of critical thinking skills and social skills was $76.81 \%$, and the remaining $23.19 \%$ was influenced by other variables not examined in this study. The implementation of discovery learning is proven to have the potential to make a significant contribution to critical thinking skills and social thinking skills which can ultimately improve students' character.

The results of this study are consistent with the results of research by Facione, Facione, and Giancarlo (2000) who reported that there was a significant correlation between critical thinking on students' character. Discovery learning models are reported to be able to develop students' critical thinking processes (Bakker, 2018). Discovery models can train and develop students' thinking skills (Asrul \& Susilo, 2018). Discovery learning makes students challenged to be more courageous in examining new facts they find and critically confirms the truth of these facts (Castronova, 2002).

Besides being able to improve students' critical thinking skills, discovery learning models can also improve students' social skills because the application of discovery models requires students to work collaboratively in solving problems (Joolingen, de Jong, Lazonder, Savelsbergh, \& Manlove, 2005). The need to collaborate will hone students' social skills, and they will be trained in how to interact with each other and respect each other's role in the group. The social-constructivist learning theory underlying the discovery learning model considers learning as a constructive and collaborative process. These theories provide the idea that students develop their understanding by working on authentic tasks in real situations, and task performance is emphasized more in collaboration with friends peers (Dunbar, 2001; Joolingen et al., 2005). Social interactions that can train students' social skills will be formed through learning that emphasizes collaboration (Penner, 1992).

Discovery learning that emphasizes collaboration in information retrieval can improve students' character. Students are allowed to interact with peers and teachers (Castronova, 2002). This condition will train students to respect each other's opinions and ideas. Students are trained to mature their thoughts and accept differences. Discovery learning also emphasizes teamwork with a fair proportion of tasks in groups. It will develop superior character in organizing tasks and taking responsibility for their respective parts.

Based on the potential contribution in developing students' character in this study, it was found that critical thinking skills had a greater contribution than social skills. This means that the contribution of critical thinking skills as a predictor variable was very strong. These results are in line with the results of research by Demirbag, Unisen, and Yesilyurt (2016); Kilic, Yazici, and Topalak (2017); Demirel, Derman, and Aran (2017) which states that there is a strong correlation between critical thinking skills and students' character. These results are 
supported by Canziani and Tullar (2017) who report that a person's character is influenced by the extent of their thinking skills, the more critical their thinking power is, the better the character they have. Developing a good attitude is by developing a good mindset (Tanriverdi, Ulusoy, \& Turan, 2012).

The effective contribution of critical thinking skills to students' characters is $64.49 \%$. Constructivist learning which is the basis of developing discovery models provides great opportunities in developing students' critical thinking skills (Asrul \& Susilo, 2018). The learning model used in this study influences students' critical thinking skills (Fuad, Zubaidah, Mahanal, \& Suarsini, 2017). Critical thinking skills are part of high-level thinking in Bloom's revised taxonomy, namely analyzing, synthesizing, and evaluating (Facione, 2011; Facione et al., 2000; Setiawati \& Corebima, 2017). Critical thinking as an intellectual and mental process by which a person succeeds in conceptualizing, analyzing, synthesizing, evaluating, and/or applying the information to formulate judgments, conclusions, or answers (Allen, 2008).

The key to student success lies in how they manage their thinking skills (Alrubaie \& Daniel, 2014). Students' critical thinking skills can be developed by directing students to make observations about natural phenomena that occur in the surrounding environment to be analyzed and given input and conclusions (Rabu, Aris, \& Tasir, 2013). Observing activities, formulating problems, asking questions, making observations and making conclusions are activities that can develop critical thinking skills (Vieira, Tenreiro-Vieira, \& Martins, 2011). All these steps are found in the discovery learning model (Arends, 2012; Castronova, 2002; Joolingen, 1999; Joolingen et al., 2005).

Students who were previously familiar with conventional methods found it difficult in the early stages of learning. They faced difficulty in observing natural phenomena that were given both in the form of narration and video. This was one of the causes of the lack of critical thinking skills possessed by students (Fahim \& Pezeshki, 2012; National Education Association, 2014). Discovery models provided steps that can help students in observing a problem as the beginning of the scientific process to practice critical thinking skills (Abdelrahman \& Abdelrahman, 2014). The syntax found in the discovery learning model trained students to become observers like scientists (Eberbach \& Crowley, 2009). Training and stimulation provided by teachers continuously in learning in schools can ultimately contribute to the development of students' critical thinking (Prince \& Felder, 2006).

In this study, social skills showed a lower contribution than students' critical thinking skills. This was due to the lack of teacher attention in developing students' social skills while learning at school. Students should be more focused on cognitive skills by ignoring other important skills (Setiawati \& Corebima, 2017) causing students to be individualistic. They consider classmates to be rivals in gaining achievements, so the willingness to help one another when there were friends who had difficulty in learning was minimal. This result is in line with the results of the Hopkins et al. (2011) study which stated that social skills were not given much attention in teaching and learning activities so that students became selfish, individualistic and did not have empathy. This lack of social skills caused a decrease in students' character, which was because students considered others around him as rivals who did not need to be helped (Hughes et al., 2011) so that student behavior did not reflect the personal character of affection as was expected in the Law on National Education System to become a noble person (Permendiknas, 2003).

Students with low social skills often underestimate other friends, they dominate conversations without allowing other friends to submit their ideas or opinions (Davies, Cooper, Kettler, \& Elliott, 2015). Students must be trained to assume the same responsibilities in learning. It is not permissible for a topic or an issue to be handled by only one student. The discovery model suggested steps needed in developing students' social skills. The syntax contained in the discovery model gave each student a role to act like scientists and play their respective roles according to the division of tasks assigned to them (Castronova, 2002; Joolingen, 1999; Uside et al., 2013). This habituation and training developed students' social skills as they interacted with their communities in the school and in the community environment, which influenced directly or indirectly their character. 
The effective contribution of social skills to the character of students in this study was found only $12.32 \%$. This contribution was smaller than the effective contribution made by critical thinking skills towards students' character. This result is attributed to the lack of attention of teachers and policyholders to the importance of developing social skills as well as teachers and students who only pursued cognitive skills as seen from values in the form of numbers.

The effective contribution of critical thinking skills and social skills to the students' character was found $76.81 \%$. These results prove that critical thinking skills and social skills simultaneously have a very significant and effective contribution to students' character. The better the students' critical thinking skills and social skills, the better is the character possessed by them. These results provided us with the input that to develop character students must empower students' critical thinking skills and social skills. These results also provide clues to further empower social skills that are still low to get more optimal results from the results that have been obtained previously.

In this study, it was found that there was a strong correlation between critical thinking skills and social skills on the characters possessed by students. The more critical the students' ability to think, the more they have strong character (Farisi, 2016); they can also choose which things are good to do and which things to avoid (Canney \& Byrne, 2006). Students will thus have a reference to act in every condition. Social skills also have an important role in the development of students' character. Students with high social skills will easily empathize with other friends, help each other and have a high concern so that noble characters are embedded in their lives. Good characters cannot be taught, they can only be trained in daily activities that are implemented from teaching and learning activities in the school environment (Puskur, 2010).

\section{CONCLUSION AND RECOMMENDATIONS}

Based on the results and discussion of this study, it can be concluded that: (1) critical thinking skills and social thinking skills together have a significant relationship with students' character in the application of discovery learning models, (2) the contribution of the correlation between critical thinking and thinking skills simultaneously and the problem of students' character on the application of discovery learning model was measured as $76.81 \%$, and (3) the effective contribution of critical thinking skills to student's character was found greater (64.49\%) than social skills $(12.32 \%)$ with reference to students' character.

The empowering character which is the affective domain and not a mastery learning can be taught by habituation. The character of students can develop if they are empowered through the integration of daily life and implementation of learning models that can lead to character development. Based on the results of the current research critical thinking skills and social skills had a major contribution to the development of students' character. A need was felt to get the attention of teachers and stakeholder as an alternative step in efforts to develop students' character. Discovery learning model can be used as an alternative learning model to improve students' critical thinking skills and social skills so that they directly or indirectly affect the character of students to become a better person. This study was limited to students in state high schools 1 Besuki in Situbondo district. This research might be more interesting if applied at all levels of the school to get more varied results concerning other thinking skills that can be a contribution to students' character. This research has implications for developing students' character through learning at school. This study found that the student's character could be developed more variedly through the learning model as one of the media. further research is needed to enrich the way in developing students' character so that many alternatives can be used.

Funding: This study received no specific financial support.

Competing Interests: The authors declare that they have no competing interests.

Authors' Contributions: All authors contributed equally to the conception and design of the study. 


\section{REFERENCES}

Abdelrahman, P., \& Abdelrahman, K. (2014). The effect of using discovery learning strategy in teaching grammatical rules to first year general secondary student on developing their achievement and metacognitive skills. International Journal of Innovation and Scientific Research, 5(2), 146-153.

Akinbobola, A. O., \& Afolabi, F. (2009). Constructivist practices through guided discovery approach: The effect on students' cognitive achievements in Nigerian senior secondary school physics. Bulgarian Journal of Science and Education Policy, 3(2), 233-252.

Allen, M. (2008). Promoting critical thinking skills in online information literacy instruction using a constructivist approach. College and Undergraduate Libraries, 15(1-2), 21-38. Available at: https://doi.org/10.1080/10691310802176780.

Alrubaie, F., \& Daniel, E. G. S. (2014). Developing a Creative thinking test for iraqi physics students. International Journal of Mathematics and Physical Sciences Research, 2(1), 80-84.

Arends, R. I. (2012). Learning to teach (5th ed.). New York: McGraw Hill.

Asrul, R., S., \& Susilo. (2018). Creative thinking analysis, motivation and concept mastery on learning of cooperative discovery model in elementary school. Journal of Primary Education, 7(1), 48-56.

Bakker, A. (2018). Discovery learning: zombie, phoenix, or elephant? Instructional Science, 46(1), 169-183. Available at: https://doi.org/10.1007/s11251-018-9450-8.

Beyer, B. K. (1987). Practical strategies for the teaching of thinking. New York: Allyn and Bacon.

Brooks, B. A., Floyd, F., Robins, D. L., \& Chan, W. Y. (2015). Extracurricular activities and the development of social skills in children with intellectual and specific learning disabilities. Journal of Intellectual Disability Research, 59(7), 678-687. Available at: https://doi.org/10.1111/jir.12171.

Canney, C., \& Byrne, A. (2006). Evaluating circle time as a support to social skills development - reflections on a journey in school-based research. British Journal of Special Education, 33(1), 19-24. Available at: https://doi.org/10.1111/j.14678578.2006.00407.x.

Canziani, B., \& Tullar, W. L. (2017). Developing critical thinking through student consulting projects. Journal of Education for Business, 92(6), 271-279. Available at: https://doi.org/10.1080/08832323.2017.1345849.

Castronova, J. A. (2002). Discovery Learning for the 21st Century: What is it and how does it compare to traditional learning in effectiveness in the 21st Century. New York: McGraw Hill.

Davies, M., Cooper, G., Kettler, R. J., \& Elliott, S. N. (2015). Developing social skills of students with additional needs within the context of the australian curriculum. Australasian Journal of Special Education, 39(1), 37-55. Available at: https://doi.org/10.1017/jse.2014.9.

Demirbag, B., Unisen, A., \& Yesilyurt, A. (2016). Training of critical thinking skills in teacher candidates and placebo effect: A quasi-experimental study. Eurasian Journal of Educational Research, 16(63), 375-392. Available at: https://doi.org/10.14689/ejer.2016.63.21.

Demirel, M., Derman, I., \& Aran, O. C. (2017). Examining graduate dissertations in the field of critical thinking: A case from Turkey. Eurasian Journal of Educational Research, 67(1), 141-159. Available at: http://dx.doi.org/10.14689/ejer.2017.67.9.

Dunbar, K. (2001). What scientific thinking reveals about the nature of cognition. In K. Crowley, C. D. Schunn, \& T. Okada (Eds.), Designing for science: Implications from everyday, classroom, and professional settings (pp. 115-140): Lawrence Erlbaum Associates Publishers.

Eberbach, C., \& Crowley, K. (2009). From everyday to scientific observation: How children learn to observe the biologist's world. Review of Educational Research, 79(1), 39-68. Available at: https://doi.org/10.3102/0034654308325899.

Efendy. (2011). Science learning applications in character building students. Seminar Nasional Sains UNESA. Surabaya.

Eggen, P., \& Kauchak, D. (2012). Strategies and models for teacher: teaching content and thinking skills (6th ed.). Boston: Pearson Education. 
Facione, P. A. (1990). Critical thinking: A statement of expert consensus for purposes of educational assessment and instruction. Research Findings and Recommendations.

Facione, P. A. (2011). Critical thinking: What it is and why it counts. Insight Assessment, 2007(1), 1-23.

Facione, P. A., Facione, N. C., \& Giancarlo, C. A. (2000). The disposition toward critical thinking: Its character, measurement, and relationship to critical thinking skill. Informal Logic, 20(1), 61-84. Available at: https://doi.org/10.22329/il.v20i1.2254.

Fahim, M., \& Pezeshki, M. (2012). Manipulating critical thinking skills in test taking. International Journal of Education, 4(1), 153-160. Available at: https://doi.org/10.5296/ije.v4i 1.1169.

Farisi, M. I. (2016). Developing the 21 st-century social studies skills through technology integration. Turkish Online Journal of Distance Education, 17(1), 16-30. Available at: https://doi.org/10.17718/tojde.47374.

Feriyanti, D. (2014). Discovery learning as a method to teach descriptive text in building students' character: A case of seventh grade students of Smp N 3 Ulujami. ETERNAL (English Teaching Journal), 5(2). Available at: https://doi.org/10.26877/eternal.v5i2.2148.

Fisher, A. (2001). Critical thinking: An introduction. London: Cambridge University Press.

Fuad, N. M., Zubaidah, S., Mahanal, S., \& Suarsini, E. (2017). Improving junior high schools' critical thinking skills based on test three different models of learning. International Journal of Instruction, 10(1), 101-116. Available at: https://doi.org/10.12973/iji.2017.1017a.

Gresham, F. M. (2016). Social skills assessment and intervention for children and youth. Cambridge Journal of Education, 46(3), 319-332. Available at: https://doi.org/10.1080/0305764x.2016.1195788.

Gresham, F. M., Elliott, S. N., Cook, C. R., Vance, M. J., \& Kettler, R. (2010). Cross-informant agreement for ratings for social skill and problem behavior ratings: An investigation of the social skills improvement system-rating scales. Psychological assessment, 22(1), 157-166. Available at: https://doi.org/10.1037/a0018124.

Gustems-Carnicer, J., \& Calderón, C. (2016). Virtues and character strengths related to approach coping strategies of college students. Social Psychology of Education, 19(1), 77-95. Available at: https://doi.org/10.1007/s11218-015-9305-y.

Hopkins, I. M., Gower, M. W., Perez, T. A., Smith, D. S., Amthor, F. R., Wimsatt, F. C., \& Biasini, F. J. (2011). Avatar assistant: Improving social skills in students with an ASD through a computer-based intervention. Journal of Autism and Developmental Disorders, 41(1 1), 1543-1555. Available at: https://doi.org/10.1007/s 10803-011-1179-z.

Hughes, C., Golas, M., Cosgriff, J., Brigham, N., Edwards, C., \& Cashen, K. (2011). Effects of a social skills intervention among high school students with intellectual disabilities and autism and their general education peers. Research and Practice for Persons with Severe Disabilities, 36(1-2), 46-61. Available at: https://doi.org/10.2511/rpsd.36.1-2.46.

Joolingen, W. v. (1999). Cognitive tools for discovery learning. International Journal of Artificial Intelligence in Education, 10, 385397. Available at: https://doi.org/10.1.1.108.5673.pdf.

Joolingen, V. W. R., de Jong, T., Lazonder, A. W., Savelsbergh, E. R., \& Manlove, S. (2005). Co-Lab: research and development of an online learning environment for collaborative scientific discovery learning. Computers in Human Behavior, 21(4), 671-688. Available at: https://doi.org/10.1016/j.chb.2004.10.039.

Kilic, I., Yazici, T., \& Topalak, S. I. (2017). Critical thinking disposition of music teachers. Eurasian Journal of Educational Research, 17(72), 185-202.

Kroeger, K. A., Schultz, J. R., \& Newsom, C. (2007). A comparison of two group-delivered social skills programs for young children with autism. Journal of Autism and Developmental Disorders, 37(5), 808-817. Available at: https://doi.org/10.1007/s10803-006-0207-x.

Laushey, K. M., \& Heflin, L. J. (2000). Enhancing social skills of kindergarten children with autism through the training of multiple peers as tutors. Journal of Autism and Developmental Disorders, 30(3), 183-193.

Lee, I.-J. (2001). The proper directions and practical ways for character education in the Korean elementary school. Asia Pacific Education Review, 2(2), 72-84. Available at: https://doi.org/10.1007/bfo3026292. 
Lerner, M., McMahon, C., \& Britton, N. (2013). Group-based social skills interventions for adolescents with higher-functioning autism spectrum disorder: A review and looking to the future. Adolescent Health, Medicine and Therapeutics, 2013(4), 2338. Available at: https://doi.org/10.2147/ahmt.s25402.

Lipman, M. (2003). Thinking in education. Cambridge: Cambridge University Press.

Logan, D. E., Kilmer, J. R., \& Marlatt, G. A. (2010). The virtuous drinker: Character virtues as correlates and moderators of college student drinking and consequences. Journal of American College Health, 58(4), 317-324. Available at: https://doi.org/10.1080/07448480903380326.

Martaida, T., Bukit, N., \& Ginting, E. M. (2017). The effect of discovery learning model on student's critical thinking and cognitive ability in junior high school. IOSR Journal of Research $\mathbb{S}^{\circ}$ Method in Education, 7(6), 1-8. Available at: https://doi.org/10.9790/7388-0706010108.

Mawaddah, N., Suyitno, H., \& Kartono. (2015). Discovery learning model learning with metacognitive approaches to improve metacognition and mathematical creative thinking ability. Unnes Journal of Mathematics Education Research, 4(1), 10-17.

McGovern, T. V., \& Miller, S. L. (2008). Integrating teacher behaviors with character strengths and virtues for faculty development. Teaching of Psychology, 35(4), 278-285. Available at: https://doi.org/10.1080/00986280802374609.

McMahon, C. M., Vismara, L. A., \& Solomon, M. (2013). Measuring changes in social behavior during a social skills intervention for higher-functioning children and adolescents with autism spectrum disorder. Journal of Autism and Developmental Disorders, 43(8), 1843-1856. Available at: https://doi.org/10.1007/s10803-012-1733-3.

National Education Association. (2014). Preparing 21st century students for a global society: An educator' s guide to the " four Cs (pp. 1-38). National Education Association.

Novotni. (2002). Sosial skills inventory: Attention-deficit hyperactivity disorder (ADHD). Florida. Retrieved from: https://secure.myadhd.com/index.php?page=About_ADHD.

Paul, R., Binker, A. J., Martin, D., Vetrano, C., \& Kreklau, H. (1989). Critical thinking handbook: 6th-9th grades. A guide for remodelling lesson plans in language arts, social studies, छ' science: Sonoma State University.

Paul, R., \& Elder, L. (2012). The miniature guide to critical thinking: Concepts and tools. Paper presented at the 27th International Conference on Critical Thinking.

Penner, D. E. (1992). Chapter 1 cognition, computers, and synthetic science: Building knowledge and meaning through modeling. Review of Research in Education, 25, 1-35. Available at: https://doi.org/https://doi.org/10.3102/0091732X025001001.

Permendiknas. (2003). Book of Law Number 20 Sisdiknas 2003. Indonesia.

Peterson, C., Park, N., Pole, N., D’Andrea, W., \& Seligman, M. E. P. (2016). Psychological distress among adolescents in Chengdu, Sichuan at 1 month after the 2008 Sichuan earthquake. Journal of Urban Health, 29(3), 504-523. Available at: https://doi.org/10.1002/jts.

Prince, M. J., \& Felder, R. M. (2006). Inductive teaching and learning methods: Definitions, comparisons, and research bases. Journal of Engineering Education, 95(2), 123-138.

Purwanto, C. E., Nugroho, S. E., \& Wiyanto. (2012). Application of guided discovery learning model in light reflection material to improve critical thinking. Unnes Physics Education Journal, 1(1), 26-32.

Puskur, B. (2010). Development of national culture and character education: School guidelines. Jakarta: Kemdiknas Balitbang Puskur.

Rabu, S. N. A., Aris, B., \& Tasir, Z. (2013). Teaching critical thinking through online instructor scaffolding: A conceptual framework. Procedia-Social and Behavioral Sciences, 97, 314-319.

Ritchhart, R., \& Perkins, D. (2005). Learning to think: The challenges of teaching thinking. The Cambridge Handbook of Thinking and Reasoning, 137, 775-802.

Scriven, M., \& Paul, R. (1987). Defining critical thinking. Paper presented at the 8th Annual International Conference on Critical Thinking and Education Reform. New York: The Foundation For Critical Thinking. 
Setiawati, H., \& Corebima, A. D. (2017). Empowering critical thinking skills of the students having different academic ability in biology learning of senior high school through PQ4R-TPS strategy. The International Journal of Social Sciences and Humanities Invention, 4(5), 3521-3526.

Sultoni, A. (2016). Character education and state progress: State comparison study. JOIES: Journal of Islamic Education Studies, 1(1), 184-207.

Sumintono, B., Tahir, L. M., Anuar, M., \& Rahman, A. (2012). Moral education in Malaysia: Challenges and implementation of character education in schools. Jurnal Pendidikan Karakter, 1, 14-22. Available at: https://doi.org/10.21831/jpk.voi1.1308.

Suphi, N., \& Yaratan, H. (2016). Effects of discovery learning and student assessment on academic success. Turkish Online Journal of Educational Technology, 2016(NovemberSpecialIssue), 829-835.

Syolendra, D. F., \& Laksono, E. W. (2019). The effect of discovery learning on students' integrated thinking abilities and creative attitudes. Journal of Physics: Conference Series, 1156(1), 012018. Available at: https://doi.org/10.1088/1742$6596 / 1156 / 1 / 012018$.

Tanriverdi, B., Ulusoy, Y. O., \& Turan, H. (2012). Evaluating teacher education curricula's facilition of the development of critical thinking skills. Eurasian Journal of Educational Research, 47, 23-40.

Unlu, S. (2018). Curriculum development study for teacher education supporting critical thinking. Eurasian Journal of Educational Research, 18(76), 165-185.

Uside, O. N., Barchock, K., \& Abura, O. (2013). Effect of discovery method on secondary school student's achievement in physics in Kenya. Asian Journal of Social Sciences and Humanities, 2(3), 351-358.

UUSPN. (2003). National Education System Law Number 20 of 2003. Indonesia.

Vieira, R. M., Tenreiro-Vieira, C., \& Martins, I. P. (2011). Critical thinking: Conceptual clarification and its importance in science education. Science Education International, 22(1), 43-54.

Weber, M., \& Ruch, W. (2012). The role of a good character in 12-year-old school children: Do character strengths matter in the classroom? Child Indicators Research, 5(2), 317-334. Available at: https://doi.org/10.1007/s12187-011-9128-0.

Wong, C., Odom, S. L., Hume, K. A., Cox, A. W., Fettig, A., Kucharczyk, S., . . Schultz, T. R. (2015). Evidence-based practices for children, youth, and young adults with autism spectrum disorder: A comprehensive review. Journal of Autism and Developmental Disorders, 45(7), 1951-1966. Available at: https://doi.org/10.1007/s 10803-014-2351-z.

Zane, T. W. (2013). Implementing critical thinking with signature assignments. New York: Spring.

Views and opinions expressed in this article are the views and opinions of the author(s), International Journal of Education and Practice shall not be responsible or answerable for any loss, damage or liability etc. caused in relation to/arising out of the use of the content. 